\title{
The Geographical Indication Pathway to Sustainability: A Framework to Assess and Monitor the Contributions of Geographical Indications to Sustainability through a Participatory Process
}

\author{
Emilie Vandecandelaere ${ }^{1, *(\mathbb{D})}$, Luis Fernando Samper ${ }^{2,3} \mathbb{D}^{\mathbb{D}}$, Andrés Rey ${ }^{2,3}$, Ana Daza ${ }^{2,3}$, Pablo Mejía ${ }^{2,3}$, \\ Florence Tartanac ${ }^{1}$ and Massimo Vittori ${ }^{3}$ \\ 1 Food and Agriculture Organization of the United Nations, Food and Nutrition Division, I-00100 Rome, Italy; \\ Florence.tartanac@fao.org \\ 2 oriGIn and 4.0 Brands, Bogota 110221, Colombia; luis.samper@4point0brands.com (L.F.S.); \\ andres.rey@arcoconsultores.co (A.R.); ana.daza@arcoconsultores.co (A.D.); \\ pablo.mejia@arcoconsultores.co (P.M.) \\ 3 The Organization for an International Geographical Indications Network (oriGIn), 1202 Geneva, Switzerland; \\ Massimo@origin-gi.com \\ * Correspondence: emilie.vandecandelaere@fao.org
}

Citation: Vandecandelaere, E.; Samper, L.F.; Rey, A.; Daza, A.; Mejía, P.; Tartanac, F.; Vittori, M. The Geographical Indication Pathway to Sustainability: A Framework to Assess and Monitor the Contributions of Geographical Indications to Sustainability through a Participatory Process. Sustainability 2021, 13, 7535. https://doi.org/10.3390/su13147535

Academic Editor: Luis

M. López-Ochoa

Received: 14 March 2021

Accepted: 18 June 2021

Published: 6 July 2021

Publisher's Note: MDPI stays neutral with regard to jurisdictional claims in published maps and institutional affiliations.

Copyright: @ FAO, 2021. Licensee MDPI, Basel, Switzerland. This article is an open access article distributed under the terms and conditions of the Creative Commons Attribution (CC BY NC SA) license (https:/ / creativecommons.org/licenses/by/bync-sa/3.0/igo/).

\begin{abstract}
Geographical Indications (GIs) are widely considered as tools to contribute to sustainability (The Food and Agriculture Organization of the United Nations-FAO, 2009; 2017), if established and well managed. While the literature may not always agree on the positive effects of GIs in all sustainability dimensions (e.g., economic, social, and environmental), there is evidence that engaging GI producers in a sustainability strategy can maximize their contribution to different components of sustainable development. FAO and oriGIn developed the sustainability strategy for GI (SSGI) to support GI producers and their associations so that they could engage in a placebased and participative approach in order to generate concrete progress and results. This paper presents original research for building both a framework and database for the selection and use of relevant sustainability indicators for GIs. A number of SSGI principles have guided the work throughout an iterative process for reviewing, selecting, and improving relevant indicators, while the Sustainability Assessment of Food and Agriculture (SAFA) has provided the structure to align with the Sustainable Development Goals (SDGs) and other widely used and recognized sustainability frameworks. As a result of this work, a database of 372 robust sustainability indicators that are relevant to GIs have been characterized to facilitate their use by practitioners. The discussion highlights the importance of the place-based approach, and the participative, inclusive process that represents the key to empowerment and the ability to develop alliances. It also focuses on action, and the need to strengthen both internal and external communication.
\end{abstract}

Keywords: geographical indications; sustainability; evaluation; indicators; territory; Sustainable Development Goals (SDG); participatory; inclusiveness

\section{Introduction}

In the effort to contribute to and achieve the Sustainable Development Goals (SDG) which form part of the international community's 2030 Agenda, territorial approaches combined with value-chain processes were identified as powerful drivers of necessary rural transformations [1]. In particular, when a local group of producers establishes and manages a geographical indication (GI), it can be used as a tool to contribute to the increasing of the sustainability of their production system by promoting a high-quality product linked to origin. Furthermore, local traditions will be preserved, natural resources protected, and the conditions to ensure fair income for producers will be provided [2]. As defined by 
the World Intellectual Property Organization (WIPO), a GI is a sign used on products that have a specific geographical origin and possess qualities or a reputation that are intrinsic to that origin [3]. This intellectual Property Right (IPR) has gained traction among more and more countries, as demonstrated by the increasing number of requests for technical assistance. With the recent entry into force of the Geneva Act of the Lisbon Agreement, which provides countries with an international registration system, the protection of GIs has been moved into the forefront, and increased attention is being placed on how GIs can be used as tools for rural development within national policies.

Literature on GIs illustrates how GIs contribute to various elements of sustainability, in particular in relation to economic and social sustainability [4-8] with references to the preservation of cultural and natural resources as part of local capital [9-11]. Another way to envisage their positive contribution to sustainability is to consider the provision of public goods, as highlighted in the special issue entitled "Geographical Indications, Public Goods, and Sustainable Development" [12]. Indeed, GIs provide a foundation to support a basket of diverse local public goods and resources, including territorial reputation [13], landscape, natural and food heritage, local culture and know-how, and economic and social effects on the territory (i.e., job creation, income, social cohesion) [14,15]. Environmental aspects have also gained increased attention, even if we are reminded that GI protection cannot be considered as an environmental tool per se but it can play a positive role in environmental conservation [16]. The GI literature has also underlined that GIs are not a magical tool and that the local conditions which can influence their establishment and management are crucial to the efficiency and local sustainability of the GI [15]. These necessary conditions can be summarized as follows $[17,18]$ : (i) the specific quality linked to origin that is well defined in the specifications (in order to demonstrate intellectual property right and ensure strong market differentiation) [19]; (ii) the collective action and territorial governance [20]; (iii) the effective marketing efforts (the GI is effectively used to market the products) [8]; and (iv) the legal framework and role of the public sector, at least pertaining to the effective protection of GIs $[7,21,22]$. Under these conditions, the GI processes have the capacity to support an endogenous approach, as the local community of producers can become primary actors in defining standards. There is a possibility to re-shape relationships along value-chains, in particular international trade, where market players usually impose their requirements on growers [23,24]. In this regard, GI processes actively enhance local governance, which is recognized as a crucial element in sustainability, to the point of being defined as the fourth pillar of sustainability in the FAO framework "Sustainability Assessment for Food and Agriculture Systems" [25].

Analysis of the contribution of GIs to sustainability reveals further issues. First, most producers are either not aware of the capacity of GI processes to contribute to sustainability or they lack the capacities to integrate all sustainability elements into the management of their GI system. Second, GI processes may also have negative externalities on their territories [26], especially when the perspective of local producers has not been integrated into the processes [27]. Therefore, engaging GI producers in a sustainability strategy could help reducing negative externalities, when they occur, and maximize the contribution of the GI scheme to sustainable development.

Aware of both the potentialities and the challenges regarding the contributions GI processes make to sustainability, both FAO and oriGIn have collaborated since 2016 to support GI producers, defined here as all value-chain actors involved in the production of the final GI product, to develop their own bottom-up GI sustainability strategy. The Sustainability Strategy for GIs (SSGI) has been endorsed by oriGIn's membership since 2017 and aims to support the engagement of producers in a strategy that will result in sustainability by traversing a roadmap through the following stages: Prioritize, Assess, and Improve, with a transversal component on Communication [28] (see Figure 1). 


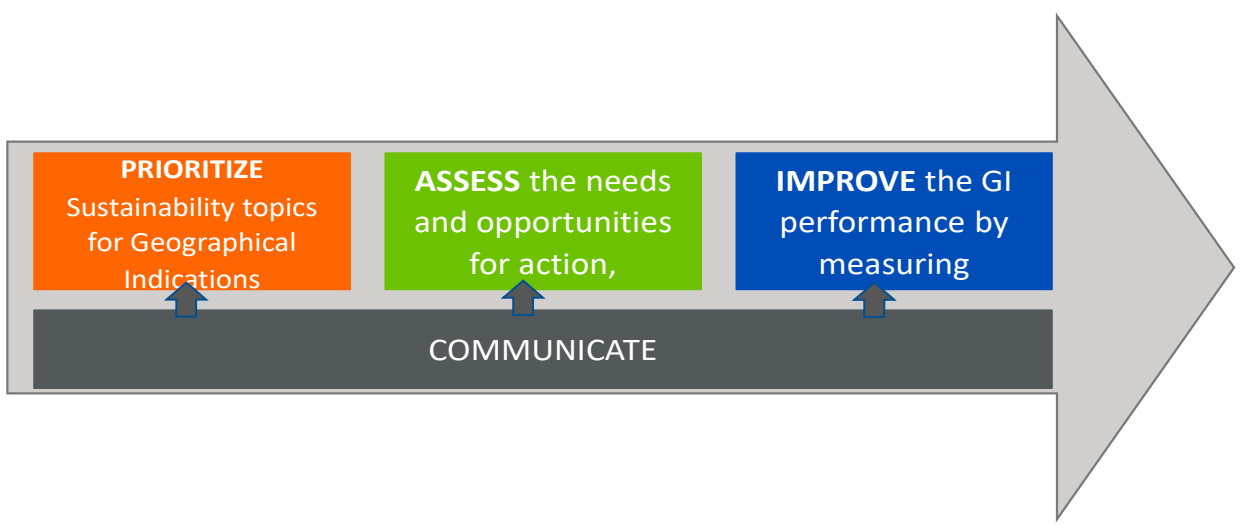

Figure 1. The roadmap for the strategy on GI sustainability and its four components.

From this viewpoint, it is crucial to provide the appropriate tools for GI producers in order to permit them to become aware of the issues related to sustainability and to agree on priorities (Prioritize), from where they can assess the current situation (Assess) and define their action plan to address the issues and increase their sustainability performance (Improve). Throughout this path, communication is crucial for both internal management and externally for public information. A major difficulty for this process is the ability to approach the sustainability of GIs in a comprehensive manner, as the literature on GIs is usually focused only on certain elements of sustainability. Although some research has begun to consider a comprehensive approach to the assessment of the sustainability of GIs, in particular the Strenght2Food project (S2F) [29], not many sources provide a holistic view.

Sustainability assessments are complex processes and require time and capacities. In the framework of the SSGI, the question is whether a comprehensive approach to GI sustainability (i.e., prioritizing issues and assessing and improving GI sustainability) can be accessible to GI producers as part of the endogenous development and place-based approach, which are at the heart of the GI processes to contribute to sustainability.

The aim of this paper is twofold:

- $\quad$ To review and compare the existing frameworks for sustainability, which could apply to GI specificities in order to identify and extract the principles and components for a tailored framework supporting the SSGI.

- To propose an original approach for the assessment of GI sustainability and a sustainability indicator database for GIs that preserves the endogenous development approach to sustainability through a place-based and participatory process.

Apart from this introduction, the paper is structured as follows. The Section 2 presents a review of the literature on GIs, explaining the five main principles of the SSGI that have guided the work on indicators and related guidelines. Section 3 discusses the process that led to the creation of a robust and integrated sustainability indicator database on GIs. The Section 4 (Results) includes a brief description of the structure of the database with a broad overview of the attributes assigned to each indicator. The discussion (Section 5) highlights a few insights related to the originality of the framework (i.e., place-based, participative and inclusive, and focus on action). The concluding remarks can be found in the Section 6.

\section{State of the Art and the Principles of a Place-Based and Participative GI Sustainability Assessment}

\subsection{Specific Contribution to Sustainability of GI Processes}

What emerges from the previously mentioned literature is a variety of specificities that can be combined so that GI processes contribute to sustainability and produce public goods. Some particular topics draw our attention.

Among public goods, biodiversity is of increasing attention in relation to the resilience of agri-food systems in the context of climate change. Similar to the other environmental component, only the producers' awareness regarding local biodiversity and their capac- 
ity and willingness to preserve it can produce positive effects and, in this case, product specifications can represent a powerful tool to preserve and even enrich local biodiversity [26,30-34]. Another public good that gains increased attention relates to diet diversity and nutrition [35], whose effects can not only be observed at the territorial level. The importance of traditional diets in nutrition and health is not recent [36-38] but focusing on GI products as a tool to address malnutrition has been ignored until today, perhaps because many of the most famous GIs belong to the wine and spirits and fatty or salted products categories. However, comparing a GI product to the standard product of the same category brings interesting insights because of various mechanisms such as the link to origin [39,40], the interest in the health aspects of fermented products [41], or the NOVA classification of foods that recognizes the nutritional advantages of unprocessed or minimally processed foods against those that have been ultra-processed [42].

Governance is another key topic, and represents the key factor in the success of achieving scale in terms of sustainability improvements. Governance is addressed in two ways in the literature on GIs. One approach is to focus on the value-chain with governance to access markets and to ensure the fair redistribution of added values [6,43-45]. The other approach looks at territorial governance, taking a broader view of its scope and impacts. This allows for the coordination of social learning with external actors, public authorities or other sectors within and outside the territory [46]. Governance is a crucial aspect in attaining efficiency of protection, rural development, and sustainability (both in terms of the long-term approach and being multifunctional) [47-50]. It also facilitates endogenous innovation processes and trajectory in a territory [51]. Finally, recognition is accorded to the potential institutional role that GIs can play in food system governance and rural development policies at a larger scale, both regional and national [52]. Of interest is the recent notion of "reflexive governance" applied to GIs when using agroecology principles as a comprehensive framework to analyse the contributions GIs make to sustainability [53]. Reflexive governance is the result of cognitive procedures and feedback to influence actors' beliefs, norms and perceptions which, as mentioned by Owen et al., are "critical for diverse stakeholders in a given space to "feel" collectively attached to a shared problem and future" so as to ensure transition towards greater sustainability. This approach highlights another key element of sustainability, namely the possibility of being a pathway to improvement rather than just a state or standard to reach. From this perspective, it makes more sense to monitor the progress made on a regular basis and in comparison to a baseline.

\subsection{Evaluation of GI Impacts}

There are important insights in the literature related to the evaluation of GIs, mostly in relation to economic results [54-60]. Economic impacts are particularly important to ensure the viability of GIs and to provide interested legislators, donors, or development agencies evidence that will stimulate them to invest in this driver of rural development [17]. Economic impacts are also the primary motivation for producers to engage in the GI process, even if the impacts on social and environmental dimensions are also considered as part of the "territorial impact" [61]. Studies evaluating the impact of the use of GIs either a diachronic approach (i.e., before and after GI registration) or a synchronic approach (i.e., a comparison of two similar products, one with a GI and the other without). The choice of method often depends on the availability of necessary data, which is often scarce (especially in developing countries). Quantitative methods are often preferred in these approaches in order to provide precise data that can be analysed by employing statistical methods and used for comparisons. Qualitative methods are used in complementarity to provide an in-depth understanding of attitudes and behaviours, and tend to be more participatory and reflective [62]. Nevertheless, demonstration of the net benefits of GIs is relatively sparse. Again, it is difficult to generalize results that vary significantly between one case and another, in their contexts, in the modalities of their establishment, in the strength of local institutions and, in particular, in the commitment and efforts of all actors in the GI value chain and the stakeholders involved. A common limit revealed in the 
evaluations, whatever their focus, is the difficulty in establishing a clear "chain of causality" that links the GI to the measured effect [62] and to separate the impact of the GI from other factors such as technological advances, quality control, advertising, or policy dynamics [63]. Indeed, many factors, events, strategies and human stories are interconnected with GI development, from the first idea discussed within the local community to GI registration and ongoing management. Actually, assessing sustainability as a whole is even more complex as it requires a holistic approach engaging broad multi-criteria assessment so as to cover the many dimensions of sustainability, while bearing in mind that any large set of indicators will still be a simplification of reality (if not a projection of the evaluator's mindset) [64]. To allow for the correct balance between a manageable number of indicators and simplification, the choice of meaningful indicators is crucial, depending on the focus and general objective. On the one hand, the objective could be to help a system monitor progress by defining integrated indicators that are specifically adapted to the particular system (for example, when assessing the quality and sustainability of small-scale systems) [65]. An opposing approach is to build a generic grid with various sets of indicators that can be applied similarly in different systems in order to allow for comparison. This is the case of the Strenght2Food project (S2F), which assesses the sustainability of various quality schemes (e.g., GI and organic), building on 23 shared indicators [29]. The definition and implementation of such a framework illustrates the importance of selecting the right balance of meaningful indicators, while also taking into account feasibility (in terms of time, resources, data availability, and capacity to interpret the quantity of data). Another difficulty in sustainability assessment is the evolution of the system as soon as it has been studied, since the influence of the system provoked sheds light on its components and values. All these elements support the preference within the SSGI to focus on a sustainability pathway which evolves and can be monitored on its own in its own grid of indicators, rather than being compared with different situations. A specific grid also allows for better understanding of the trade-off inherent in complex decision-making processes. Explicit consideration of a trade-off at the beginning of the process, where there are clear acceptability criteria, is an important component of sustainability assessments [66].

\subsection{Principles to Guide the SSGI}

Learning from the literature about the specific contribution of GIs to sustainability and impact assessment, the following principles have been defined to guide the development of a framework with relative indicators in the framework of the SSGI (Box 1) [67]. 
Box 1. Principles of the sustainability strategy for GI.

Sustainability is a pathway and not a state: Thus, it is envisaged as a continuous improvement process. Rather than an approach with certain thresholds that categorize a state of sustainability, the SSGI aims to empower GI organizations by choosing relevant goals based on their own priorities relevant to their contexts. This principle implies that the priorities and actions of GIs must be evaluated regularly. The priorities may change in an evolving world where new challenges to sustainability arise continuously, whereas the effectiveness of sustainability initiatives undertaken must be constantly analysed through iterative processes.

A place-based framework adapted to GI specificities: GIs are intrinsically linked to their territory of origin, including to natural and cultural dimensions. It is therefore crucial to recognize the importance of the local resources and conditions for GI impacts. Such local anchorage is also the foundation for an extended territorial strategy, building on GI governance. For the framework, this implies: (1) the recognition of governance as a driver of sustainability; (2) the need to provide a list of indicators within which GI stakeholders can select the most appropriate to their specific systems, including cultural and natural dimensions and biodiversity; and (3) the need to combine indicators at farm, value chain, and territorial level.

Inclusiveness and participatory process: GIs are voluntary and collective endeavours involving different producers through participative processes. Bottom-up approaches are considered to be more effective in the long term and it is important to envisage local consultation and engagement of producers and allies so that shared priorities and goals are defined, creating the stakeholder dialogues necessary for future cooperation. All GI systems and organizations should be able to engage in the strategy of sustainability. Therefore, the framework should support several types of GIs where there may be different degrees of maturity of the organizations, resource capacity, and knowledge bases for sustainability requirements. In this sense, GI organizations should be able to undertake their sustainability analysis without incurring significant expenses and without facing barriers related to capacity or resources. Additionally, and taking into account possible limits to access to information, self-assessment is considered.

A sound and operational approach: Sustainability is a complex matter that needs a solid scientific approach to avoid greenwashing. Sustainability is about commitment, and engaging in sustainability means acknowledging the challenges and mistakes that require concrete initiatives and actions. Therefore, the framework must benefit from academic work and concrete experience of sustainability in order to be operational and facilitate actions. At the same time, many frameworks already exist and some are well recognized. Thus, the SSGI must be consistent with other recognized sustainability frameworks, not only to ensure that it is solid and robust and combines different types of indicators (e.g., qualitative/quantitative, subjective/objective) but also to allow bridges between the frameworks and indicators used by other value chain actors and potential allies. This will avoid duplication, and provide a common ground for an enhanced and necessary dialogue among stakeholders or possible allies for devising new policies and initiatives.

A collective and individual exercise where cooperation is key: A collective sustainability path is built on the sum of the different individual paths from each GI stakeholder along the value chain. It is important to have both individual and collective indicators to look at both the value-chain and territory levels. No single stakeholder can confront all sustainability challenges. Indicators and initiatives can also be added as a result of alliances that can be developed on strategic topics with relevant specialists, governments, or value chain actors. Both cooperation that initiates within the GI organization and extends with allies and individual engagement are crucial. The framework must be adapted for the use at both levels in order to support processes of internal engagement and external alliances, and to be used for the implementation of collective and individual sustainability strategies.

\section{Materials and Methods}

In line with the SSGI objectives and principles defined, the research opted for the development of a framework including an integrated set of relevant indicators for GIs and the necessary guidelines to facilitate the understanding of local issues, definition of priorities, assessment of the selected priority topics, monitoring, and improvement of the particular GI system in relation to its sustainability performance. The methodology builds on the aforementioned SSGI principles, which have guided the work throughout an iterative process for reviewing, selecting, and improving relevant indicators, along with a process that can be categorized by the following main steps. 


\subsection{Identification of the Framework Foundations}

Primary background research was conducted in order to understand the fundamental sustainability requirements, including those defined by market actors. The Sustainability Assessment of Food and Agriculture (SAFA) [25] was benchmarked against the SDGs [68], sustainability requirements from the market, and commonly used disclosure standards (GRI, Global Reporting Initiative and SASB, Sustainability Accounting Standards Board $[69,70])$. SAFA was selected as the best foundation for GI sustainability in terms of credibility (SAFA is backed by the United Nations with multi-stakeholder support; it is science-based with well-developed tools), structure and taxonomy (topics considered), value chain coverage (all agricultural and food sectors included, with a good fit across the value chain while the producer level is emphasized), alignment with SDGs, and frameworks used by key brands and retailers. SAFA guidelines are recognized among the relevant global initiatives to assess the sustainability of farms, farming systems, and supply chains, starting with a precise definition of "sustainability", and to facilitate comparability of the results [71]. Its flexibility in application (it can be completed with additional criteria and indicators) and applicability to GIs has been also recognized, with the inclusion of relevant topics (governance, culture and traditions within the social pillar, or food quality and biodiversity).

\subsection{Review of Pre-Existing and Relevant Indicators}

A review of reputable initiatives and key sustainability indicators was conducted on recognized sources in the area of agriculture and food sustainability. The overall goal was to guarantee that the initial set of indicators were as broad as possible in order to cover all key characteristic of GIs. In particular:

- Covering three levels of interest: local producers (farm, enterprise and/or operation/processing unit), value-chains, and territory;

- Ensuring different modalities for data collection, including self-assessment in given circumstances to facilitate an inclusive and bottom-up approach;

- Combining different types of indicators (e.g., individual or collective, objective/subjective, quantitative/qualitative, levels of complexity and cost for data collection, etc.)

Initially a total of 84 possible indicator sources were compiled that can be categorized as follows:

- General methodology and guidelines for sustainability assessment [64,66,72,73];

- Anchors for the database related to SDGs and SAFA [25,68,74-78];

- Specific frameworks related to agriculture and food topics: sustainable agriculture and value chains [79-81], agroecology [82,83], climate change and resilience [84], nutrition sensitive agriculture [85];

- $\quad$ GI specific sustainability assessment [86-88];

- Downstream market frameworks [69,70,89-91];

- Sources associated with measurement of specific topics: carbon footprint [92], water footprint [93], biodiversity [94], social dimension [95,96], fair trade practices [97], and empowerment of women [98];

- Additional indicators from specific certification approaches [99-104]; and

- $\quad$ Specific agricultural sectors $[89,105,106]$.

The review resulted in a list of 543 indicators, among which 23 indicators were specifically created, and 79 indicators were inspired from different sources to tackle specific angles (in particular in the governance pillar). Other set of indicators (28) relate to the "private sector contributions to SDGs" (FAO contribution building on the United Nations Conference on Trade and Development (UNCTAD) indicators), and specific indicators were created to cover the sub-theme of health and nutrition in the social pillar. 


\subsection{Consolidation of SAFA Structure and Taxonomy}

Based on the previous exercise, the original SAFA structure was complemented with additional themes and sub-themes. Then, a process of consolidation led to a more operational reclassification with a balance between the different pillars and themes regarding the number of indicators in order to ensure a good mix between subjective and objective indicators. Indicators were also reviewed according to the topics and subtopics in the database. In this sense, some indicators were moved to other sub-themes. In totally, 31 indicators were reassigned to different sub-themes.

\subsection{The Characterization of Indicators}

Once structured vertically within the four SAFA pillars, themes, and sub-themes, the work concentrated on the horizontal structure with the characterization of each indicator. In addition to the source, the columns were designed to characterize each of the indicators, in particular its applicability (i.e., whether it can be applied to different GI sectors and contexts) and detailing its relation to other sustainability frameworks and key sustainability certification schemes used in agriculture. The characterization also reflects proportionality in order to better measure the effort in relation to the size of the operation, both from a collective and individual perspective. The initial "vocation" of each indicator was also determined (i.e., whether it is primarily designed for internal process and management or oriented to external communication). Finally, some key indicators were highlighted for a number of sub-themes. These indicators might be considered default indicators for their respective sub-themes, as they are frequently used for the better understanding of the performance by a number of sources, frameworks, and organisations. The criteria used to define these default indicators also included the importance of the sub-theme, the possible low complexity for many GI and ability to self-assess.

\subsection{The Final in Depth Review Process-Discarding and Finetuning Indicators}

Apart from the normal quality control procedures, the objectives of the final in-depth review were:

1. Precision: each indicator reviewed for clarity and explicit definition of its calculation, suggesting amendments when needed. Numeric indicators focusing on relative rather than absolute performance were preferred.

2. Integration: indicators that had similar formulas were unified following the easier to interpret, ensuring the clarity of the formula and requirements in addition to the capacity of the producer to collect the necessary information to measure the indicator. Four indicators were combined with others, while forty indicators were further contrasted.

3. The creation of the "original formula" and "formula column" to show suggested amendments to the formula, defined by the original source, mostly focused on relative rather than absolute numbers and providing better guidance for the collection of data adapted to the GI context.

4. Explanations for each individual indicator was enhanced, which required the creation of the "Possible Examples and/or significance" column. Finally, an individual indicator analysis resulted in a "default indicator" column, in order to highlight key indicators to be considered for GI practitioners, which may be used in the forthcoming guide as default indicators for given subthemes.

\section{Results}

\subsection{The Database}

This iterative indicator review resulted in a dynamic database, allowing users to choose the most relevant indicators according to the specific needs of the GI involved, following the priorities defined in the first stage of the strategy. There are 372 technically robust sustainability indicators that have been classified and deemed relevant to GI. A total of 111 indicators are SAFA sourced, whereas 261 come from other sources (see Table 1). 
There are 114 indicators on environmental integrity, 85 on social well-being, 62 on good governance, and 111 on economic resilience.

Table 1. Main source of indicators in the four pillars (top 10).

\begin{tabular}{|c|c|c|c|c|c|}
\hline Sourced or Adapted From & Environmental & Social & Governance & Economic & Total \\
\hline SAFA & 48 & 19 & 22 & 22 & 111 \\
\hline COSA & 6 & 8 & 0 & 24 & 38 \\
\hline GRI & 14 & 12 & 5 & 4 & 35 \\
\hline UNCTAD-FAO & 12 & 6 & 7 & 9 & 34 \\
\hline SDG & 9 & 9 & 3 & 3 & 24 \\
\hline Authors & 1 & 3 & 11 & 5 & 20 \\
\hline $\begin{array}{l}\text { FAO and University of Florence } \\
\text { guidelines for evaluation }\end{array}$ & 0 & 1 & 2 & 16 & 19 \\
\hline FAO (SHARP) & 9 & 1 & 2 & 5 & 17 \\
\hline $\begin{array}{l}\text { Barilla BCFN-Food Sustainability } \\
\text { Index }\end{array}$ & 3 & 1 & 1 & 8 & 13 \\
\hline IFPRI-Feed the future & 0 & 3 & 0 & 5 & 8 \\
\hline Others (16 sources) & 12 & 22 & 9 & 10 & 53 \\
\hline Total & 114 & 85 & 62 & 111 & 372 \\
\hline
\end{tabular}

These indicators are organized under 22 themes with a total of 63 sustainability topics or sub-themes for determining sustainability priorities. Among the 63 sub-themes, five governance sub-themes are considered as a priority sustainability topic for every GI organization, as the success of a GI system heavily depends on its ability to create the conditions for collective action to benefit its GI members and to establish significant alliances through a representative body. A total of 159 indicators are included as "key or default indicators" for most of the sub-themes listed. Thus, after a given GI organization has selected its priority subthemes, some will directly provide a key/default indicator for consideration. Finally, the structure allows for the recognition of the SDG convergence. After contrasting all indicators in the database against the objectives and targets of the SDG, there was a direct relationship between 16 of the 17 SDG proposed by the United Nations at the global level for the 2030 sustainability agenda. This exercise must be complemented individually by producers or by GI with respect to the goals at the local level proposed by each country or region. Based on the above-mentioned taxonomy, the structure was designed to characterize all indicators related to each sub-theme. A description and definition, when applicable to each attribute, is provided in Table 2. The list of themes and subthemes is provided in Appendix A.

Table 2. Description of the final database containing SSGI indicators.

\begin{tabular}{|c|c|c|}
\hline \multicolumn{3}{|c|}{ Part 1. Sustainability themes } \\
\hline SAFA's main structure & $\begin{array}{l}4 \text { pillars: Good Governance, Environmental } \\
\text { Integrity, Economic Resilience and Social } \\
\text { Well-being } \\
22 \text { themes } \\
63 \text { sustainability subthemes }\end{array}$ & 371 indicators numbered for easy reference. \\
\hline \multicolumn{3}{|c|}{ Part 2. Indicator source and formula and characterization } \\
\hline \multirow{5}{*}{$\begin{array}{l}\text { There may be one or more } \\
\text { indicator for each } \\
\text { sustainability subtheme. }\end{array}$} & Indicator & Name of indicator \\
\hline & Original Formula & $\begin{array}{l}\text { Explicit or implied mathematical formula to obtain indicator, } \\
\text { mentioning variables to be used to obtain the indicator. If not a } \\
\text { mathematical formula, then the qualitative definition of the } \\
\text { indicator. }\end{array}$ \\
\hline & Formula: & Shows the modified formula suggested. \\
\hline & Indicator Source Code: & Designates the code of each indicator source. \\
\hline & Indicator Source & $\begin{array}{l}\text { Shows the original source of the indicator, whether SAFA or any } \\
\text { of the other } 25 \text { direct sources used. }\end{array}$ \\
\hline
\end{tabular}


Table 2. Cont

Part 2. Indicator source and formula and characterization

Qualitative/quantitative:

Source (internal/external)

Objective/subjective

Process/impact

Requirements

Default Indicator

Possible Examples/Significance
Describes whether the indicator is numeric or not and, if so, whether it is derived from a mathematical formula or is qualitative in nature.

As a result of the expert's discussion, it was deemed appropriate to define the vocation of the indicator, i.e., if it should be used primarily for internal management or could be used for external communication.

Illustrates whether the information required to obtain the indicator comes from data or information obtained from within the GI organization (internal), requires the participation and/or cooperation of third parties, or comes from a public source (external).

Provides an indication as to whether the information is or can be found from a third-party source or obtained internally following protocols that ensure it is rigorous (objective), corresponds to perceptions, or is derived from information that can be considered partial or not reflecting a large or representative sample or database (subjective).

Corresponds to indicators that show the level of performance in terms of actions and/or initiatives taking place (process) versus the expected result of such initiatives (impact).

Describes the basic information requirements needed to obtain the indicator.

Shows whether, in the consultant's opinion, the GI practitioner should consider the marked indicator always for current or near future sustainability exercises. It also provides elements to consider when gathering the necessary information for their future use if the information is not currently available.

It briefly describes (in lay terms) examples of use or the key aspect the indicator identifies or shows.

\section{Part 3: Standards Applicability}

In this section, the correspondence between the selected indicators and those indicator frameworks accepted internationally, market, or science based is presented, allowing for possible use in other sustainability frameworks and cooperation through joint initiatives.

\begin{tabular}{|c|c|c|}
\hline \multirow[t]{4}{*}{$\begin{array}{l}\text { Broad sustainability } \\
\text { frameworks }\end{array}$} & SDG & $\begin{array}{l}\text { This column shows the reference to the SDG objective associated } \\
\text { with each indicator. }\end{array}$ \\
\hline & GRI & $\begin{array}{l}\text { This column shows the reference to the corresponding GRI } \\
\text { indicator. This cross reference is important as many downstream } \\
\text { players use this standard, implying a connection to the topics and } \\
\text { indicators that consumer groups, investors, and other } \\
\text { stakeholders regularly see. The relevant GRI topic indicator code } \\
\text { is identified. }\end{array}$ \\
\hline & Ethos & $\begin{array}{l}\text { This column cross-references indicators with the Ethos Social } \\
\text { Responsibility framework. }\end{array}$ \\
\hline & UNCTAD/FAO & $\begin{array}{l}\text { The cross-reference to UNCTAD work is very useful for } \\
\text { policy-makers and those interested in the relationship between } \\
\text { SDGs and agriculture, as it focuses on the contribution of the } \\
\text { private sector towards implementation of the SDGs. }\end{array}$ \\
\hline \multirow[t]{3}{*}{ Agriculture and Food } & SAFA & $\begin{array}{l}\text { The relevant SAFA indicator code is identified here for easy } \\
\text { reference. }\end{array}$ \\
\hline & Fairtrade & $\begin{array}{l}\text { The relevant indicator used in the Fairtrade seal certification } \\
\text { system is identified. }\end{array}$ \\
\hline & Rainforest & $\begin{array}{l}\text { The relevant indicator used in the Rainforest Alliance seal } \\
\text { certification system is identified. }\end{array}$ \\
\hline \multirow[t]{4}{*}{ Key GI sectors } & \multirow{4}{*}{$\begin{array}{l}\text { Reviews whether each indicator can be } \\
\text { considered relevant for four selected GI } \\
\text { macro-sectors }\end{array}$} & Dairy and Meat \\
\hline & & Fruits and Vegetables \\
\hline & & Coffee, Cocoa, and Tea \\
\hline & & Wines and spirits \\
\hline
\end{tabular}


Table 2. Cont.

\section{Part 4: Indicator Usage}

In this section, a number of variables are defined to help the GI representative select the most relevant indicators according to their organizational experience and sustainability expertise, the maturity level in their sustainability pathway or a desired iteration process, choosing the best option to measure their performance.

Complexity: deals with the

difficulty to obtain the data

\section{Cost}

Does obtaining the information or calculating the indicator require direct costs payable to a third party or the procurement of costly devices?

Scale for cost. Low: No cost or low budget indicator; Medium: Indicator requires a specific, affordable budget; High: Obtaining indicator implies a significant expense

Requirement of internal resources Does obtaining the information or calculating the indicator require a significant amount of internal resources, complex procedures in terms of time from the individual or the GI organization?

Scale for Requirement of Internal Resources. Low: Current staff does not require significant time to obtain indicator; Medium: Reasonable staff time needs to be allocated to obtain indicators; High: Significant internal resources required to obtain indicator.

Depth of analysis Does obtaining, calculating or interpreting the indicator require highly qualified individuals or skills belonging to the organization or not?

Scale for Depth of analysis: Low-Indicator is simple to explain/obtain/understand; Medium-Obtaining/interpreting Indicator requires reasonable knowledge/specialization of key individuals; High - Staff needs training — external consultants hired to obtain and use indicator

\begin{tabular}{|c|c|c|}
\hline \multirow{4}{*}{$\begin{array}{l}\text { Value Chain Stakeholder } \\
\text { Interest }\end{array}$} & \multirow{4}{*}{$\begin{array}{l}\text { Illustrates whether the indicator is } \\
\text { susceptible to the interest of other actors in } \\
\text { the value chain }\end{array}$} & Farmers or rural producers \\
\hline & & Processing operations \\
\hline & & Distribution actors \\
\hline & & Consumer/retail actors \\
\hline \multirow[t]{3}{*}{ Indicator Application } & \multirow{3}{*}{$\begin{array}{l}\text { Refers to the particular domain that the } \\
\text { indicator can reflect. } \\
\text { Non-exclusive options }\end{array}$} & $\begin{array}{l}\text { Territorial dimension: indicator related to } \\
\text { people/practices/capital in the territory or origin }\end{array}$ \\
\hline & & $\begin{array}{l}\text { Value chain dimension: indicator related to value chain actors } \\
\text { beyond the territory of the origin product, including processors, } \\
\text { distributors and retailers }\end{array}$ \\
\hline & & $\begin{array}{l}\text { Society dimension: outside of the territory/distribution } \\
\text { perspective. This indicator relates to society value and or public } \\
\text { goods beyond the territory of the origin product (e.g., heritage for } \\
\text { all and the world, guarantees of quality, truth in labelling, } \\
\text { traceability and transparency, etc.) }\end{array}$ \\
\hline \multirow[t]{2}{*}{ Scope } & \multirow[t]{2}{*}{$\begin{array}{l}\text { Whether the indicator can be used to } \\
\text { measure progress in individual operations } \\
\text { and/or can reflect collective progress. }\end{array}$} & $\begin{array}{l}\text { Collective } \\
\text { For example, deforestation. } \\
\text { Some can be used both individually and collectively, such as } \\
\text { access to employee or producer social security benefits. }\end{array}$ \\
\hline & & $\begin{array}{l}\text { Individual } \\
\text { For example, greenhouse emissions may be obtainable and } \\
\text { reliable at the individual level }\end{array}$ \\
\hline \multirow[t]{2}{*}{ Self-Assessment } & \multirow[t]{2}{*}{$\begin{array}{l}\text { Whether the indicator can be obtained } \\
\text { through internal process }\end{array}$} & $\begin{array}{l}\text { Yes } \\
\text { Internally obtained information or methods such as internal } \\
\text { qualifications of performance or internal perceptions }\end{array}$ \\
\hline & & No \\
\hline
\end{tabular}

\subsection{Guidelines for Prioritization, Assessment and Improvement}

In association with the database, the SSGI framework includes a series of guidelines and toolkits to guide the user through the different stages (i.e., prioritization, assessment and improvement and communication) along the roadmap (see Figure 2). 


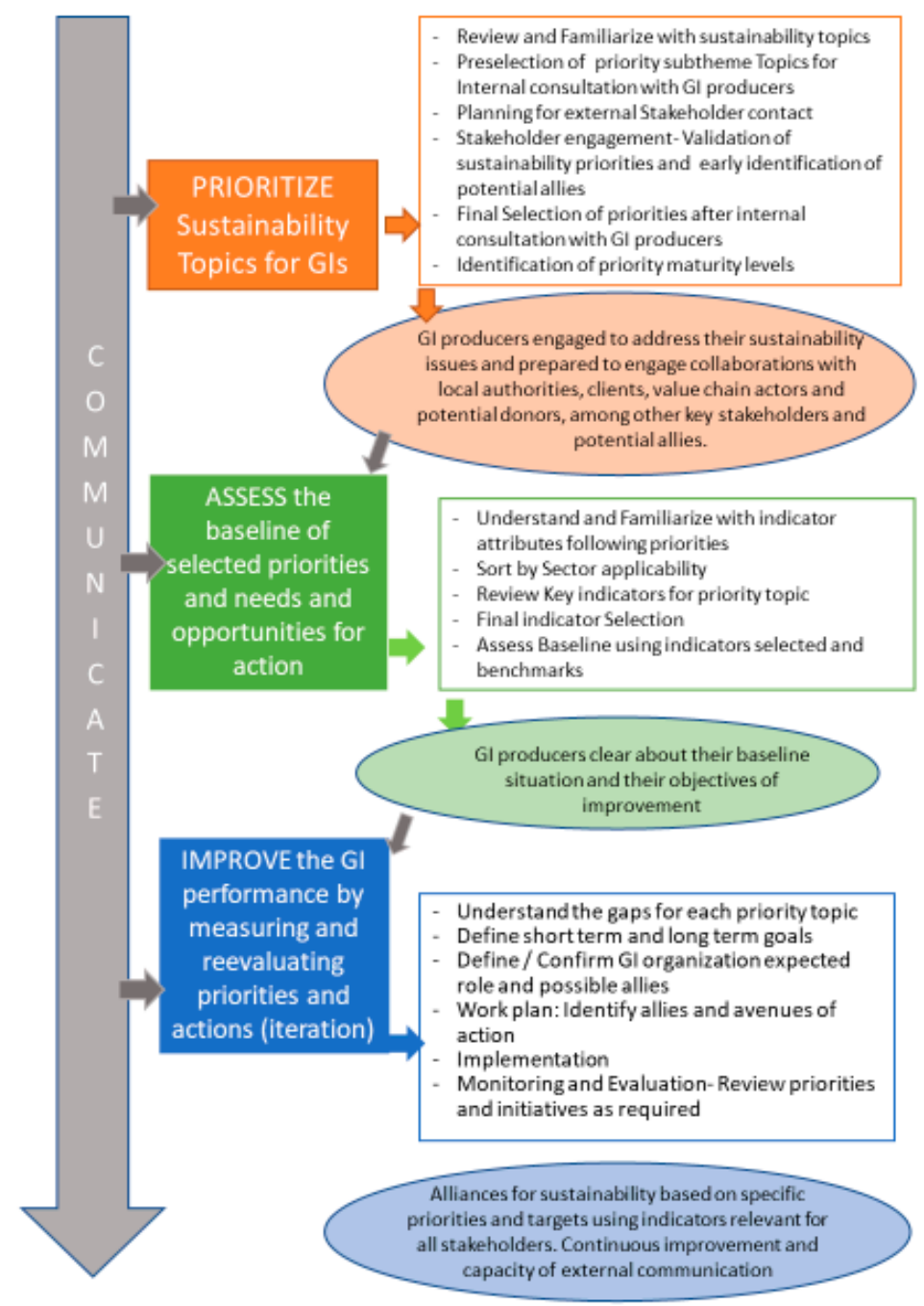

Figure 2. The SSGI roadmap in detail.

The prioritization guidelines and associated toolkit helps GI organizations and producers create their own specific pathway to sustainability by identifying their issues and priorities in terms of sustainability and along the way building alliances with key stakeholders. It guides the stakeholders through seven steps, to be developed in a participatory manner. The prioritization guide and toolkit have been prepared and tested thanks to the involvement of Marcala coffee, a GI producer in Honduras. Their contribution was crucial to ensuring the functionality of the approach. The guidelines for assessment and improvement have been applied to the defined priorities, permitting participants to select the GI indicators that are most consistent with their priorities and relevant to their local context. The guide provides a step-by-step approach to using the different filters in the database, following four main phases: the establishment of the assessment system; organization of the baseline assessment and indicator goals; definition of the workplan for improvement; and communication. Recommendations, depending on the types of GI (e.g., recent, mature) and minimum requirements are included along the phases (e.g., default indicators, minimum number of indicators by pillars and themes, minimum number of quantitative data, etc.).

\section{Discussion}

The work presented aims to address the need for a specific sustainability framework for GIs that allows GI producers to define their own sustainability pathway and assess and improve accordingly their contribution to the SDGs in an operational manner. It consists, 
therefore, of: (1) reviewing the existing framework and indicators; and (2) building a consistent and original framework aligned to reputable sustainability indicators, sources and frameworks, from both academic and market perspectives. This effort is still a work in progress, as the use of the sustainability indicator database and related guides (assessment and improvement) still needs to be tested in the field and on concrete cases in order to better calibrate the indicators and fine-tune guidance to users. The current database and draft guidelines represent an important result that can be discussed in the light of the objectives of the paper and principles of the SSGI regarding the aim to:

- Build a sound approach for GI sustainability through a benchmark of reputable sources;

- Provide an original framework that reflects GI processes endogeneity, i.e., (1) the place-based approach and (2) the participative and inclusive process.

A discussion is also provided in relation to the concrete use of this framework in actions.

\subsection{A Sound and Operational Approach}

The initial benchmark process reviewed more than 84 sources for sustainability frameworks and indicators, from the most general to the most specialized approaches (either by sector or type of issue), from different stakeholder's points of view (United Nations, researcher, buyer, certifier, etc.), with the intention of ensuring alignment with the most used or reputable frameworks and also allowing for checking linkages in the database. It is acknowledged that an operational framework, such as the one being developed, can allow a large number of GIs and producers to start their own sustainability pathway. At the same time, however, at least two risks may arise. First, there may be a gap between the conceptual level of certain indicators and the producers' knowledge and capacities. Second, there is often a trade-off between simplification and loss of information. The confrontation between so many indicators allows the selection of the most appropriate from the viewpoint of language and the producers, but also provides possibilities to reformulate and create new indicators as required. Functionality, from the viewpoint of the producers' ability to implement the framework, will be determined by the capacity to develop easy guidelines, if not a digital tool.

\subsection{The Place-Based Framework}

The framework that has been developed is structured so that each GI system can define its own set of priorities and indicators selected from the database, while ensuring some minimum requirements and recommendations for the quality of the results. This is possible thanks to the fundamental stage of prioritization. GI stakeholders, employing a participatory process and supported by specialists (through alliances), can identify their own sustainability issues in the four pillars (i.e., economic, social, environmental, governance), and agree on their priorities based on their maturity level, referring to importance currently being given to each priority topic and the needs to be addressed in the near, medium or long term, as well as its potential impact on a GI product by taking into consideration stakeholder expectations, external pressures, risks and opportunities. This prioritization exercise also allows for an early consideration of trade-offs and best decisionmaking through a participatory process and for the selection of indicators in relation to the local situation and context. The strength of this approach permits the assessment and understanding of the specific conditions and mechanisms linked to a context and sector, and makes real improvement possible by addressing priorities. On the other hand, this will not allow for easy comparison between different GIs (except for the default indicators, in particular regarding governance), which could reduce emulation between GI systems and the generalization of some insights arising from specific experiences. 


\subsection{Participative and Inclusive Process}

Participative and inclusive processes are the key not only to enhancing the place-based component, but also because they drive empowerment and, thus, rural and sustainable development. The participatory process is the backbone of the SSGI implementation, and is ensured by the different steps described in the guidelines, alternating group discussion and collective agreement with the in-house practitioner in charge of work preparation. Inclusiveness is twofold. It concerns the specific process of the assessment of GI sustainability, by ensuring that each type of stakeholder is represented throughout the use of the framework, and at the global strategy level, to ensure that any GI group can engage (whatever their level of resources and capacities). From this last viewpoint, the flexibility of indicators and methods used to collect data have been carefully considered. The database categorizes indicators depending on their complexity and provides tips for data collection in a way that facilitates self-assessment by GI stakeholders themselves. This means GI stakeholders own the process at all times. Clearly all information is not easily available, which is why the strategy emphasizes, from the very beginning, on the creation of alliances with qualified institutions.

In this way, the use of these sustainability indicators contributes to social development through the empowerment and democratization of decision-making, while the assessment process, including methods and data employed to assess progress, remains accessible to all [64]. This is an important component of SDGs so that no one is left behind and stakeholders are both empowered during the process and free to decide their own goals and commitments. On the negative side, this approach may be at the cost of scientific quality. Therefore, a few limits and guidance are provided through the guidelines in order to ensure the minimum level of quality. Guidance is also adapted to the diversity of GIs, including those that are just starting their path to sustainability and the more mature GI systems, which can use the database to define indicators of higher complexity.

\subsection{A Framework Designed for Actions}

This tailored approach also enhances the possibility of embarking on a sustainability pathway that includes concrete actions towards sustainability improvement. The assessment is not so much oriented towards research and discovering the causal relation between a result and a factor, but rather on leading to the definition and implementation of an action plan that will improve the system as a whole, and the perspective of developing alliances along the way to increase the impact on agreed upon priorities. The continuous pathway to improvement supposes regular assessment and monitoring of the changes of the indicators over time, as well as the consequent adjustments to the action plan. In this perspective, thanks to the data compiled over time on specific issues and actions taken, it will be possible to:

- Raise producers' awareness of the importance of sustainability and what they can do to improve it;

- Support the monitoring of changes and improvement through the use of indicators that are related to internal management (at the levels of farm, value chain and territory);

- Support credible communication with buyers, consumers, NGOs, public authorities, on the contribution of the GI system to sustainability and SDGs, with concrete data;

- Enhance communication and secure cooperation with key stakeholders and allies, using other renowned frameworks and sustainability systems, by improving the ability to agree and use indicators for joint initiatives.

Field-testing of the prioritization guidelines illustrates the link to action well. Marcala coffee GI producers identified the issues and priorities. The producer then spontaneously discussed the necessary actions to take to address the issues. For example, producers have defined a short-term goal to "Develop a coherent narrative capable of generating loyalty and appropriation" in order to "increase the value added" as part of their action plan. The topic of communication is crucial, within the GI organization and externally with key audiences. Communication not only supports producers' engagement and alliances, but 
also helps provide relevant information concerning both the remaining challenges and progress made.

Finally, by enhancing the reporting, the framework can also support, if needed, selfcertification systems for sustainability. It is innovative, as it is based on continuous improvement instead of a dual static system (i.e., sustainable, yes or no). Indeed, there are very few examples of certification based on continuous improvement today, although the situation looks promising as in the case of Wood of Alps [107].

\section{Conclusions}

The SSGI framework is still a work in progress, as feedback from operators and practitioners needs to be integrated during field-testing so as to fine tune aspects of the indicators' characterization and the guidelines with user-friendly modalities. On this basis, a toolkit will be developed to facilitate the operational (and hopefully digital) use of the combination of guidelines and database.

Until now, most of the conceptual work has been completed through the review of existing frameworks and indicators that are relevant to GI sustainability and built on the key principles of the SSGI. The process directly supports empowerment and leadership in improving sustainability locally, and the results of the use of the framework by many GI organizations in different contexts will result in better understanding the influence of local conditions (including the importance of cooperation and alliances) on the evolution of more sustainable systems. On the other hand, the main limitations reside in the principles of flexibility and self-assessment that may reduce the capacity of the final toolkit to produce data that can make appropriate comparisons among GIs. The database is based on existing frameworks in the agricultural and food sectors, which represent most GIs, but it could work as well for handicraft products. Additional work on the database is needed to complete or specify indicators that are more appropriate for the non-agricultural sectors. Furthermore, the database could be used in the given product sectors as a sustainability tool, even if these producer group sectors have not confirmed a GI.

In order to capitalize on this framework and tools, many perspectives should be considered, depending on interest and requests from partners. The following represent examples of actions and projects that may be considered:

- Document the use of the framework for different cases and sectors to provide illustrations, lessons learned and best practices on GI sustainability;

- Taylor the use of the framework for project evaluation;

- Develop a platform to centralize the data resulting from the assessments and monitoring; these data may be useful for practitioners or academics to develop knowledge of GI and sustainability;

- Facilitate individual and global reporting and communication on progress made and GI contributions to sustainability;

- Adapt the guidelines for non-GI value chains that care for sustainability based on local tailored approaches such as a broader contribution to SDGs.

Author Contributions: Conceptualization, E.V.; methodology, E.V. and L.F.S.; validation, E.V., F.T. and M.V.; formal analysis, E.V. and L.F.S.; investigation, L.F.S., A.R., A.D. and P.M.; data curation, L.F.S., A.R., A.D. and P.M.; writing-original draft preparation, E.V.; writing-review and editing, E.V., L.F.S., F.T. and M.V.; supervision, E.V. and L.F.S.; project administration, E.V., F.T. and M.V.; All authors have read and agreed to the published version of the manuscript.

Funding: This research received no external funding.

Institutional Review Board Statement: Not applicable.

Informed Consent Statement: Not applicable.

Acknowledgments: The framework presented here benefited from precious comments from internationally recognized experts, through the task force established for the Sustainability Strategy for GI (SSGI): Armelle Mazé and Fançois Casabianca from INRAE, French National Research Institute for 
Agriculture, Food and Environment, Sabine Edelli from INAO, French National Institute for Quality and Origin, Giovanni Belletti from University of Florence, Filippo Arfini from University of Parma, Jan Landert from FIBL, Swiss Research Institute of Organic Agriculture, Martin Muñoz Sanchez from Tequila GI organization, Valentina Pizzamiglio from Parmigiano Reggiano GI organization, Claude Vermot-Desroches from Comté cheese GI organization, Maria Chiara Ferrarese from the certification company CSQA.

Conflicts of Interest: The authors declare no conflict of interest.

Disclaimer: The views expressed in this publication are those of the author(s) and do not necessarily reflect the views or policies of the Food and Agriculture Organization of the United Nations.

\section{Appendix A. List of Themes and Sub-Themes in the Four Dimensions with Number of Indicators}

\begin{tabular}{|c|c|c|c|c|c|c|c|c|c|c|c|}
\hline Theme & Sub-Theme & $\begin{array}{l}\text { Number of } \\
\text { Indicators }\end{array}$ & Theme & Sub-Theme & $\begin{array}{l}\text { Number of } \\
\text { Indicators }\end{array}$ & Theme & Sub-Theme & $\begin{array}{l}\text { Number of } \\
\text { Indicators }\end{array}$ & Theme & Sub-Theme & $\begin{array}{l}\text { Number of } \\
\text { Indicators }\end{array}$ \\
\hline \multicolumn{3}{|c|}{ Economic Resilience } & \multicolumn{3}{|c|}{ Good Governance } & \multicolumn{3}{|c|}{ Environmental Integrity } & \multicolumn{3}{|c|}{ Social Well Being } \\
\hline Investment & $\begin{array}{l}\text { Community } \\
\text { investment }\end{array}$ & 2 & Accountability & $\begin{array}{l}\text { Holistic } \\
\text { audits }\end{array}$ & 4 & $\begin{array}{l}\text { Animal } \\
\text { welfare }\end{array}$ & $\begin{array}{l}\text { Animal } \\
\text { Health }\end{array}$ & 4 & $\begin{array}{l}\text { Cultural } \\
\text { diversity }\end{array}$ & $\begin{array}{l}\begin{array}{l}\text { Food } \\
\text { sovereignty }\end{array} \\
\end{array}$ & 1 \\
\hline Investment & Costs & 15 & Accountability & Responsibility & 2 & $\begin{array}{l}\text { Animal } \\
\text { welfare }\end{array}$ & $\begin{array}{l}\text { Freedom from } \\
\text { Stress }\end{array}$ & 2 & $\begin{array}{l}\text { Cultural } \\
\text { diversity }\end{array}$ & $\begin{array}{l}\text { Indigenous } \\
\text { knowledge }\end{array}$ & 2 \\
\hline Investment & $\begin{array}{l}\text { Internal } \\
\text { investment }\end{array}$ & 4 & Accountability & Transparency & 8 & Atmosphere & Air quality & 4 & $\begin{array}{l}\text { Decent } \\
\text { livelihood }\end{array}$ & $\begin{array}{l}\text { Capacity } \\
\text { development }\end{array}$ & 3 \\
\hline Investment & $\begin{array}{l}\text { Long ranging } \\
\text { investment }\end{array}$ & 2 & Ethics & Due diligence & 2 & Atmosphere & $\begin{array}{l}\text { Greenhouse } \\
\text { gases }\end{array}$ & 11 & $\begin{array}{l}\text { Decent } \\
\text { livelihood }\end{array}$ & $\begin{array}{l}\text { Education } \\
\text { and training }\end{array}$ & 7 \\
\hline Investment & Profitability & 11 & Ethics & $\begin{array}{l}\text { Mission } \\
\text { statement }\end{array}$ & 3 & Biodiversity & $\begin{array}{l}\text { Ecosystem } \\
\text { diversity }\end{array}$ & 12 & $\begin{array}{l}\text { Decent } \\
\text { livelihood }\end{array}$ & $\begin{array}{l}\text { Fair access to } \\
\text { means of } \\
\text { production }\end{array}$ & 4 \\
\hline $\begin{array}{l}\text { Local } \\
\text { economy }\end{array}$ & Contribution & 7 & $\begin{array}{l}\text { Holistic } \\
\text { Management }\end{array}$ & $\begin{array}{l}\text { Full-cost } \\
\text { accounting }\end{array}$ & 1 & Biodiversity & $\begin{array}{l}\text { Genetic } \\
\text { Diversity }\end{array}$ & 5 & $\begin{array}{l}\text { Decent } \\
\text { livelihood }\end{array}$ & Quality of life & 9 \\
\hline $\begin{array}{l}\text { Local } \\
\text { economy }\end{array}$ & $\begin{array}{l}\text { Local } \\
\text { procurement }\end{array}$ & 2 & $\begin{array}{l}\text { Holistic } \\
\text { Management }\end{array}$ & $\begin{array}{l}\text { Sustainability } \\
\text { management } \\
\text { plan }\end{array}$ & 11 & Biodiversity & $\begin{array}{l}\text { Genetic } \\
\text { Species }\end{array}$ & 6 & Demography & $\begin{array}{l}\text { Producer } \\
\text { demographics }\end{array}$ & 3 \\
\hline $\begin{array}{l}\text { Local } \\
\text { economy }\end{array}$ & Value creation & 4 & Participation & $\begin{array}{l}\text { Conflict } \\
\text { Resolutions }\end{array}$ & 2 & Biodiversity & $\begin{array}{l}\text { Sustainable } \\
\text { fisheries }\end{array}$ & 2 & Equity & $\begin{array}{l}\text { Gender } \\
\text { equality }\end{array}$ & 7 \\
\hline $\begin{array}{l}\text { Product } \\
\text { quality and } \\
\text { information }\end{array}$ & Food Quality & 2 & Participation & $\begin{array}{l}\text { Stakeholder } \\
\text { dialogue }\end{array}$ & 17 & Land & $\begin{array}{l}\text { Land } \\
\text { degradation }\end{array}$ & 5 & Equity & $\begin{array}{l}\text { Non discrimi- } \\
\text { nation }\end{array}$ & 2 \\
\hline $\begin{array}{l}\text { Product } \\
\text { quality and } \\
\text { information }\end{array}$ & Food safety & 7 & Rule of law & $\begin{array}{l}\text { Civic } \\
\text { Responsibility }\end{array}$ & 1 & Land & Land use & 10 & Equity & $\begin{array}{l}\text { Support to } \\
\text { vulnerable } \\
\text { people }\end{array}$ & 2 \\
\hline $\begin{array}{l}\text { Product } \\
\text { quality and } \\
\text { information }\end{array}$ & $\begin{array}{l}\text { Product } \\
\text { information }\end{array}$ & 4 & Rule of law & Legitimacy & 7 & Land & Soil quality & 9 & $\begin{array}{l}\text { Human safety } \\
\text { and health }\end{array}$ & $\begin{array}{l}\text { Public health } \\
\text { and nutrition }\end{array}$ & 3 \\
\hline Vulnerability & Diversification & 8 & Rule of law & $\begin{array}{l}\text { Remedy, } \\
\text { restoration } \\
\text { and } \\
\text { prevention }\end{array}$ & 1 & $\begin{array}{l}\text { Materials and } \\
\text { energy }\end{array}$ & Energy Use & 6 & $\begin{array}{l}\text { Human safety } \\
\text { and health }\end{array}$ & $\begin{array}{l}\text { Workplace } \\
\text { safety and } \\
\text { health } \\
\text { provisions }\end{array}$ & 14 \\
\hline Vulnerability & Liquidity & 8 & Rule of law & $\begin{array}{l}\text { Resource } \\
\text { appropriation }\end{array}$ & 3 & $\begin{array}{l}\text { Materials and } \\
\text { energy }\end{array}$ & Material Use & 7 & Labour rights & Child labor & 4 \\
\hline Vulnerability & $\begin{array}{l}\text { Risk } \\
\text { management }\end{array}$ & 9 & & & & $\begin{array}{l}\text { Materials and } \\
\text { energy }\end{array}$ & $\begin{array}{l}\text { Waste } \\
\text { Reduction } \\
\text { and Disposal }\end{array}$ & 8 & Labour rights & $\begin{array}{l}\text { Employment } \\
\text { relations }\end{array}$ & 10 \\
\hline Vulnerability & $\begin{array}{l}\text { Stability of } \\
\text { market }\end{array}$ & 24 & & & & Water & Water quality & 10 & Labour rights & Forced labor & 2 \\
\hline Vulnerability & $\begin{array}{l}\text { Stability of } \\
\text { production }\end{array}$ & 1 & & & & Water & $\begin{array}{l}\text { Water } \\
\text { withdrawal }\end{array}$ & 13 & Labour rights & $\begin{array}{l}\text { Freedom of } \\
\text { association } \\
\text { and rights to } \\
\text { bargaining }\end{array}$ & 2 \\
\hline \multirow[t]{4}{*}{ Vulnerability } & $\begin{array}{l}\text { Stability of } \\
\text { supply }\end{array}$ & 1 & & & & & & & $\begin{array}{l}\text { Unbiased } \\
\text { trading } \\
\text { practices }\end{array}$ & $\begin{array}{l}\text { Responsible } \\
\text { buyers }\end{array}$ & 2 \\
\hline & & & & & & & & & $\begin{array}{l}\text { Unbiased } \\
\text { trading } \\
\text { practices }\end{array}$ & $\begin{array}{l}\text { Rights of } \\
\text { suppliers }\end{array}$ & 2 \\
\hline & & & & & & & & & $\begin{array}{l}\text { Human safety } \\
\text { and health }\end{array}$ & $\begin{array}{l}\text { Public health } \\
\text { and nutrition }\end{array}$ & 6 \\
\hline & & 111 & & & 62 & & & 114 & & & 85 \\
\hline
\end{tabular}

\section{References}

1. FAO. The State of Food and Agriculture Leveraging Food Systems for Inclusive Rural Transformation; FAO: Rome, Italy, 2017; 181p.

2. FAO. Linking People, Places and Products. In A Guide for Promoting Quality Linked to Geographical Origin and Sustainable Geographical Indications; Vandecandelaere, E., Arfini, F., Belletti, G., Marescotti, A., Eds.; FAO: Rome, Italy, 2009. Available online: http:/ / www.fao.org/3/i1760e/i1760e.pdf (accessed on 10 May 2021).

3. World Intellectual Property Organization (WIPO): Geographical Indications. Available online: https://www.wipo.int/geo_ indications/en/ (accessed on 27 April 2021).

4. Barham, E.; Sylvander, B. (Eds.) Labels of Origin for Food: Local Development, Global Recognition; Cabi: Wallingford, UK, 2011; pp. $45-62$.

5. Van de Kop, P.; Sautier, D.; Gerz, A. Origin Based Products: Lessons For Proper Market Development; Royal Tropical Institute (KIT) and French Agricultural Research Centre for International Development (CIRAD): Amsterdam, The Netherlands, 2006. 
6. Reviron, S.; Thevenod-Mottet, E.; El Benni, N. Geographical indications: Creation and distribution of economic value in developing countries. In NCCR Working Paper; NCCR Trade: Bern, Switzerland, 2009.

7. Barjolle, D. Geographical indications and protected designations of origin: Intellectual property tools for rural development objectives. In Research Handbook on Intellectual Property and Geographical Indications; Gangjee, D., Ed.; Part 3; Edward Elgar Publishing: Cheltenham, UK, 2015; pp. 1-26.

8. Tregear, A. Proximity and Typicity: A Typology of Local Food Identities in the Marketplace. In From Local Food to Localised Food, Anthropology of Food; Amilien, V., Holt, G., Eds.; Open Edition Journal: Sallebœuf, France, 2007.

9. Bérard, L.; Marchenay, P. Tradition, regulation and intellectual property: Local agricultural products and foodstuffs in France. In Valuing Local Knowledge: Indigenous Peoples and Intellectual Property Rights; Brush, S.B., Stabinsky, D., Eds.; Island Press: Washington, DC, USA, 1996.

10. Mancini, M.C. Geographical Indications (GIs) and Sustainable Rural Development: Exploring the Connections; University of Missouri: Columbia, MI, USA, 2005.

11. Tregear, A. What is "Typical Local Food"? An Examination of Territorial Identity in Foods Based on Development Initiatives in the Agrifood and Rural Sectors; Working paper 58; University of Newcastle Upon Tyne, Centre for Rural Development: Newcastle, UK, 2001.

12. Geographical Indications, Public Goods, and Sustainable Development. Available online: https://www.mdpi.com/journal/ sustainability/special_issues/Geographical_Indications_Public_Goods_Sustainable_Development (accessed on 5 July 2021).

13. Begalli, D.; Capitello, R.; Agnoli, L. Territorial-based marketing strategies for typical agro-food products: Issues and perspectives. In Agricultural Management Strategies in a Changing Economy; Popescu, G., Vasile, A.J., Eds.; IGI-Global: Hershey, PA, USA, 2015; Chapter 2, pp. 30-51.

14. Arfini, F.; Cozzi, E.; Mancini, M.C.; Ferrer-Perez, H.; Gil, J.M. Are Geographical Indication Products Fostering Public Goods? Some Evidence from Europe. Sustainability 2019, 11, 272. [CrossRef]

15. Belletti, G.; Marescotti, A.; Touzard, J.M. Geographical Indications, Public Goods and Sustainable Development: The roles of actors' strategies and public policies. World Dev. 2017, 98, 45-57. [CrossRef]

16. Belletti, G.; Canada, J.S.; Marescotti, A.; Vakoufaris, H. Linking Protection of Geographical Indications to the Environment: Evidence from the European Union Olive-oil Sector. Land Use Policy 2015, 48, 94-106. [CrossRef]

17. FAO-EBRD. Strengthening Sustainable Food Systems through Geographical Indications: An Analysis of Economic Impacts; Vandecandelaere, E., Teyssier, C., Barjolle, D., Jeanneaux, P., Fournier, S., Beucherie, O., Eds.; FAO: Rome, Italy; EBRD: London, UK, 2018; p. 135. Available online: www.fao.org/3/a-i8737en.pdf (accessed on 28 March 2021).

18. Sylvander, B.; Wallet, F.; Isla, A. Under What Conditions Geographical Indications Protection Schemes Can Be Considered as Public Goods for Sustainable Development? In Territorial Governance, Local Development, Rural Areas and Agrofood Systems; Torre, A., Traversac, J.B., Eds.; Springer: Heidelberg, Germany, 2012; pp. 185-202.

19. Tregear, A.; Arfini, F.; Belletti, G.; Marescotti, A. Regional Foods and Rural Development: The Role of Product Qualification. J. Rural Stud. 2007, 23, 12-22. [CrossRef]

20. Quiñones-Ruiz, X.F.; Penker, M.; Belletti, G.; Marescotti, A.; Scaramuzzi, S. Why Early Collective Action Pays Off: Evidence from Setting Protected Geographical Indications. Renew. Agric. Food Syst. 2016, 1, 1-14.

21. Barjolle, D.; Jeanneaux, P. Raising Rivals' Costs Strategy and Localised Agrofood Systems in Europe. Int. J. Food Syst. Dyn. 2012, 3, 11-21.

22. Barjolle, D.; Sylvander, B. PDO and PGI Products: Market, Supply Chains and Institutions; Final Report; European Commission: Brussels, Belgium, 2000.

23. Quinonez-Ruiz, X.F.; Penker, M.; Vogl, C.R.; Samper Gartner, L.F. Can Origin Labels Re-Shape Relationships Along International Supply-Chains? The Case of Café de Colombia. Int. J. Commons. 2015, 9, 416-439. Available online: https://www.jstor.org/ stable/26522831 (accessed on 6 May 2021).

24. FAO. Impact of International Voluntary Standards on Smallholder Market Participation in Developing Countries-A Review of the Literature; Loconto, A., Dankers, C., Eds.; FAO: Rome, Italy, 2014.

25. FAO. SAFA Sustainability Assessment of Food and Agriculture Systems Guidelines Version 3.0; FAO: Rome, Italy, 2014.

26. Bowen, S.; Valenzuela Zapata, A. Geographical Indications, Terroir, and Socioeconomic and Ecological Sustainability: The Case of Tequila. J. Rural Stud. 2009, 25, 108-119. [CrossRef]

27. Samper, L.F.; Quiñones-Ruiz, X.F. Towards a Balanced Sustainability Vision for the Coffee Industry. Resources 2017, 6, 17. [CrossRef]

28. FAO. The Sustainability Strategy for Geographical Indication; Food and Agriculture Organization (FAO): Rome, Italy, 2017.

29. Arfini, F.; Bellassen, V. Sustainability of European Food Quality Schemes Multi-Performance, Structure, and Governance of PDO, PGI, and Organic Agri-Food Systems; Springer: Cham, Switzerland, 2019; 567p, ISBN 978-3-030-27508-2. [CrossRef]

30. Bérard, L.; Marchenay, P. Local Products and Geographical Indications: Taking Account of Local Knowledge and Biodiversity. Int. Soc. Sci. J. 2006, 187, 109-116. [CrossRef]

31. Boisvert, V. From the Conservation of Genetic Diversity to the Promotion of Quality Foodstuff: Can the French Model of 'Appellation d'Origine Controlee' be Exported? CAPRI Working Paper No. 49; International Food Policy Research Institute, Environmental and Production Technology Division: Washington, DC, USA, 2006.

32. Garcia, C.; Marie-Vivien, D.; Kushalappa, C.G.; Chengappa, P.G.; Nanaya, K.M. Geographical Indications and Biodiversity in the Western Ghats, India. Mt. Res. Dev. 2007, 27, 206-210. [CrossRef] 
33. Thévenod-Mottet, E. Geographical Indications and biodiversity. In Agriculture, Biodiversity and Markets; Lockie, S., Carpenter, D., Eds.; Earthscan: London, UK, 2010; pp. 201-212.

34. Larson, J. Relevance of Geographical Indications and Designations of Origin for the Sustainable Use of Genetic Resources; Global Facilitation Unit for Underutilized Species: Rome, Italy, 2007.

35. FAO. The Nutrition and Health Potential of Geographical Indication Foods; FAO: Rome, Italy, 2021.

36. FAO-WHO. Rome Declaration on Nutrition. Conference Outcome Document; Paper Presented at Second International Conference on Nutrition; FAO: Rome, Italy; WHO: Geneva, Switzerland, 2014. Available online: www.fao.org/3/ml542e/ML542E.pdf (accessed on 15 February 2021).

37. FAO-WHO. Sustainable Healthy Diets—Guiding Principles; FAO: Rome, Italy; WHO: Geneva, Switzerland, 2019.

38. Burlingame, B.; Dernini, S. Sustainable diets; Linking Nutrition and Food Systems; CABI Publishing: Oxon, UK, 2018; 280p.

39. FAO-Bioversity. Sustainable Diets and Biodiversity; Directions and Solutions for Policy, Research and Action. In Proceedings of the International Scientific Symposium Biodiversity and Sustainable Diets United against Hunger, Rome, Italy, 3-5 November 2010; Burlingame, B., Dernini, S., Eds.; Food and Agriculture Organization (FAO): Rome, Italy, 2010.

40. Mason, P.; Lang, T. Sustainable Diets: How Ecological Nutrition Can Transform Consumption and the Food System; Routledge: Oxon, UK, 2017; 353p.

41. Nicklaus, S.; Divaret-Chauveau, A.; Chardon, M.L.; Roduit, C.; Kaulek, V.; Ksiazek, E.; Dalphin, M.L.; Karvonen, A.M.; Kirjavainen, P.; Pekkanen, J.; et al. Pasture Study Group. The Protective Effect of Cheese Consumption at 18 Months on Allergic Diseases in the First 6 Years. Allergy 2019, 74, 788-798. [CrossRef]

42. Monteiro, C.A.; Cannon, G.; Moubarac, J.-C.; Levy, R.B.; Louzada, M.L.C.; Jaime, P.C. The UN Decade of Nutrition, the NOVA Food Classification and the Trouble with Ultra-Processing. Pub. Health Nutr. 2018, 21, 5-17. [CrossRef]

43. Jeanneaux, P.; Mélo, A. Social Capital as a Specific Common: Application to PDO Comté Economic Performance. In Proceedings of the $\mathrm{XVI}^{\circ}$ Biennial IASC Conference Practicing the Commons, Utrecht, The Netherlands, 10-14 July 2017.

44. Quiñones-Ruiz, X.F.; Penker, M.; Belletti, G.; Marescotti, A.; Scaramuzzi, S.; Barzini, E.; Pircher, M.; Leitgeb, F.; Samper-Gartner, L.F. Insights Into The Black Box of Collective Efforts for the Registration of Geographical Indications. Land Use Policy 2016, 57, 103-116. [CrossRef]

45. Gereffi, G.; Humphrey, J.; Sturgeon, T. The Governance of Global Value Chains. Rev. Int. Polit. Econ. 2005, 12, 78-104. [CrossRef]

46. Quiñones Ruiz, X.F.; Nigmann, T.; Schreiber, C.; Neilson, J. Collective Action Milieus and Governance Structures of Protected Geographical Indications for Coffee in Colombia, Thailand and Indonesia. Int. J. Commons. 2020, 14, 329-343. [CrossRef]

47. Traversac, J.B. Cooperation and Governance in Wine Territories: A New Institutional Economic Analysis. In Territorial Governance, Local Development, Rural Areas and Agrofood Systems; Torre, A., Traversac, J.B., Eds.; Springer: Berlin/Heidelberg, Germany, 2012; pp. 159-183.

48. Chappuis, J.M.; Sans, P. Actors' Coordination: Governance Structures and Institutions in Supply Chains of Protected Designation of Origin. In The Socioeconomics of Origin Labelled Products in Agro-Food Supply Chains: Spatial, Institutional and Co-Ordination Aspects; Sylvander, B., Barjolle, D., Arfini, F., Eds.; Series Actes et Communications; INRA: Paris, France, 2000 ; Volume 17.

49. Edelmann, H.; Quiñones-Ruiz, X.; Penker, M.; Scaramuzzi, S.; Broscha, K.; Jeanneaux, P.; Belletti, G.; Marescotti, A. Social Learning in Food Quality Governance-Evidences from Geographical Indications Amendments. Int. J. Commons. 2020, 14, 108-122. [CrossRef]

50. Kizos, T.; Koshaka, R.; Penker, M.; Piatti, C.; Reinhard Vogl, C.; Uchiyama, Y. The Governance of Geographical Indications: Experiences of Practical Implementation of Selected Case Studies in Austria, Italy, Greece and Japan. Br. Food J. 2017, 119, 2863-2879. [CrossRef]

51. Belmin, R.; François Casabianca, F.; Meynard, J.M. Contribution of Transition Theory to the Study of Geographical Indication. Environ. Innov. Soc. Transit. 2018, 27, 32-47. [CrossRef]

52. Conneely, R.; Mahon, M. Protected Geographical Indications: Institutional Roles in Food Systems Governance and Rural Development. Geoforum 2015, 60, 14-21. [CrossRef]

53. Owen, L.; Udall, D.; Franklin, A.; Kneafsey, M. Place-Based Pathways to Sustainability: Exploring Alignment between Geographical Indications and the Concept of Agroecology Territories in Wales; MDPI: Basilea, Switzerland, 2020; 23p.

54. Areté. Study on Assessing the Added Value of PDO/PGI Products, Executive Summary; Study Commissioned by the European Commission; European Commission: Brussels, Belgium; Luxembourg, 2013.

55. Coulet, T. Assessing the economic impact of GI protection. In Extending the Protection of Geographical Indications: Case Studies of Agricultural Products in Africa; Blakeney, M., Coulet, T., Getachew, A.M., Mahop, M.T., Eds.; Routledge: London, UK, 2012; pp. 101-120.

56. Rangnekar. The Socio-Economics of Geographical Indications: A Review of Empirical Evidence from Europe; Issue Paper No. 8; International Centre for Trade and Sustainable Development: Geneva, Switzerland; The United Nations Conference on Trade and Development: Geneva, Switzerland, 2004.

57. Jena, P.R.; Grote, U. Impact Evaluation of Traditional Basmati Rice Cultivation in Uttarakhand State of Northern India: What Implications Does It Hold for Geographical Indications? World Dev. 2012, 40, 1895-1907. [CrossRef]

58. Jeongwook, S.; MacPherson, A. The Impact of Geographical Indication on the Revitalisation of a Regional Economy: A Case Study of "Boseong" Green Tea. Area 2007, 39, 518-527. 
59. Vakoufaris, H. The Impact of Ladotyri Mytilinis PDO Cheese on the Rural Development of Lesvos Island, Greece. Local Environ. 2010, 15, 27-41. [CrossRef]

60. European Commission. Study on Economic Value of EU Quality Schemes, Geographical Indications (GIs) And Traditional Specialties Guaranteed (TSGs), Final Report. 2020. Available online: https://op.europa.eu/en/publication-detail/-/publication/ a7281794-7ebe-11ea-aea8-01aa75ed71a1 (accessed on 12 April 2021).

61. Barjolle, D.; Paus, M.; Perret, A. Impacts of Geographical Indications: Review of Methods and Empirical Evidences. In IAAE Congress 2009. Available online: http://ageconsearch.umn.edu/bitstream/51737/2/PaperIAAE2009_85.pdf (accessed on 10 April 2021).

62. Belletti, G.; Marescotti, A. Evaluating the Effects of Protecting Geographical Indications: Scientific Context and Case Studies. In The Effects of Protecting Geographical Indications. Ways And Means of their Evaluation; Swiss Federal Institute of Intellectual Property: Berne, Switzerland, 2011; pp. 31-121.

63. Bramley, C. A Review of the Socio-Economic Impact of Geographical Indications: Considerations for the Developing World; WIPO Worldwide Symposium on Geographical Indications: Lima, Peru, 2011; pp. 1-22.

64. Bell, S.; Morse, S. Sustainability Indicators: Measuring the Immeasurable, 2nd ed.; Earthscan: London, UK, 2008.

65. Peana, C.; Migliorini, P.; Sottile, F. A Methodology for the Sustainability Assessment of Agri-Food Systems: An Application to the Slow Food Presidia Project. Ecol. Soc. 2014, 19, 24. [CrossRef]

66. Morrison-Saunders, A.; Pope, J. Conceptualising and Managing Trade-Offs In Sustainability Assessment. Environ. Impact Assess. Rev. 2013, 38, 54-63. [CrossRef]

67. FAO and oriGIn. Sustainability Assessment Indicators for Geographical Indications (GIs); Report of the Online Expert Meeting, 23 July 2020; FAO: Rome, Italy, 2020; p. 11.

68. SDG. Global Indicator Framework for the Sustainable Development Goals and Targets of The 2030 Agenda for Sustainable Development. Adopted by the General Assembly (A/RES/71/313), Annual Refinements Contained in E/CN.3/2018/2 (Annex II), E/CN.3/2019/2 (Annex II), and 2020 Comprehensive Review Changes (Annex II) and Annual Refinements (Annex III) Contained in E/CN.3/2020/2, p. 21. Available online: https://unstats.un.org/sdgs/indicators/Global\%20Indicator\%20Framework $\% 20$ after\%202020\%20review_Eng.pdf (accessed on 11 March 2021).

69. Global Reporting Initiative 2016-2019. Consolidated Set of GRI Sustainability Reporting Standards; Global Reporting Initiative: Amsterdam, The Netherlands, 2019.

70. SASB. Conceptual Framework. Sustainability Accounting Standards Board: San Francisco, California. 2017. Available online: https:/ / www.sasb.org/wp-content/uploads/2020/02/SASB_Conceptual-Framework_WATERMARK.pdf (accessed on 11 March 2020).

71. Schader, C.; Grenz, J.; Meier, M.S.; Stolze, M. Scope and Precision of Sustainability Assessment Approaches to Food Systems. Ecol. Soc. 2014, 19, 42. [CrossRef]

72. Pintérd, L.; Hardib, P.; Martinuzzic, A.; Hall, J. Bellagio STAMP: Principles for Sustainability Assessment and Measurement. Ecol. Indic. 2012, 17, 20-28. [CrossRef]

73. Latruffe, L.; Diazabakana, A.; Bockstaller, C.; Desjeux, Y.; Finn, J.; Kelly, E.; Ryan, M.; Uthes, S. Measurement Of Sustainability In Agriculture: A Review of Indicators. Stud. Agric. Econ. 2016, 118, 123-130. [CrossRef]

74. FAO. SAFA Indicators; FAO: Rome, Italy, 2013.

75. FAO. Progress Report on the SDGs, Tracking Progress on Food and Agriculture-Related SDGs Indicators 2020; Methodological Annex; FAO: Rome, Italy, 2020. Available online: http:/ / www.fao.org/sustainable-development-goals/indicators/en/ (accessed on 11 March 2021).

76. FAO. Guidelines on Data Disaggregation for SDG Indicators Using Survey Data; FAO: Rome, Italy, 2021. Available online: https: / / doi.org/10.4060/cb3253en (accessed on 5 July 2021).

77. FAO. FAO and the SDGs Indicators: Measuring Up to the 2030 Agenda for Sustainable Development; FAO: Rome, Italy, 2015.

78. UNCTAD. Guidance on Core Indicators for Entity Reporting on Contribution towards Implementation of the Sustainable Development Goals; United Nations Conference on Trade and Development: Geneva, Switzerland, 2019; 60p. Available online: https: / / unctad.org/en/pages / PublicationWebflyer.aspx?publicationid=2469 (accessed on 10 February 2021).

79. Sustainable Agriculture Network. 2018. Available online: https://static1.squarespace.com/static/59d44f074c0dbfb29da45615/t/ 5af9bb93758d46ec30b13ada/1526316225479/Sustainable+Agriculture+Framework.pdf (accessed on 12 February 2021).

80. FAO. Operational Guidelines for the Design, Implementation and Harmonization of Monitoring and Evaluation Systems for Climate-Smart Agriculture; FAO: Rome, Italy, 2019.

81. FAO. Developing Sustainable Food Value Chains Guiding Principles; FAO: Rome, Italy, 2014; p. 75.

82. FAO. TAPE Tool for Agroecology Performance Evaluation; Process of Development and Guidelines for Application Test Version; FAO: Rome, Italy, 2019; 98p. Available online: http:/ / www.fao.org/3/ca7407en/ca7407en.pdf (accessed on 5 March 2021).

83. FAO. The 10 Elements of Agroecology. Guiding the Transition to Sustainable Food and Agricultural Systems; FAO: Rome, Italy, 2018. Available online: http:/ / www.fao.org/3/19037EN/i9037en.pdf (accessed on 5 March 2021).

84. FAO. Self-Evaluation and Holistic Assessment of Climate Resilience of Farmers and Pastoralists. Biodiversity E Ecosystem Services in Agricultural Production Systems; Choptiany, J., Graub, B., Phillips, S., Colozza, D., Dixon, J., Eds.; FAO: Rome, Italy, 2015.

85. FAO. Compendium of Indicators for Nutrition Sensitive Agriculture; Herforth, A., Nicolò, G., Veillerette, B., Dufour, C., Eds.; FAO: Rome, Italy, 2016. 
86. Strength2Food. Report Detailing the Methods and Indicators for Measuring the Social, Environmental and Economic Impacts of FQS, SFSC and Varying PSFP Policies on Agri-Food Chain Participants and Rural Territories. Strengthening European Food-Chain Sustainability by Quality and Procurement Policy. European Union's Horizon 2020 Research and Innovation Programme. Deliverable 3.2 Report; Strength2Food: Brussels, Belgium, 2016.

87. Guillén Calvo, Cristina Consuegra and Laura Estrada, Colombian-Swiss Intellectual Property Project (COLIPRI); Federal Institute of Intellectual Property (IPI). Guide to Assessing Conditions and Impacts of Geographical Indications. 2017. Available online: https://www.ige.ch/fileadmin/user_upload/recht/entwicklungszusammenarbeit/GI_Impact_Guide_ENG.pdf (accessed on 5 July 2021).

88. FAO; UNiFI. Evaluating Geographical Indications; Guide to Tailor Evaluations for the Development and Improvement of Geographical, Indications; Belletti, G., Marescotti, A., Vandecandelaere, E., Teyssier, C., Eds.; (Forthcoming); FAO: Rome, Italy; University of Florence: Florence, Italy, 2021; p. 160.

89. Bonsucro. Bonsucro Production Standard for Smallholder Farmers. Version 1.0. Bonsucro-The Global Sugar Cane Platform. 2018. Available online: https://www.bonsucro.com/wp-content/uploads/2018/06/Bonsucro-PS-for-Smallholder-FarmersEnglish-Final-June-2018.pdf) (accessed on 5 March 2021).

90. Rainforest Alliance. Norma Para Agricultura Sostenible Para Producción Agrícola y Ganadera de Fincas y Grupos de Productores; Versión 1.2; Rainforest Alliance: New York, NY, USA, 2017; p. 60.

91. Barilla Center for Food and Nutrition (BCFN). FSI-Food Sustainability Index_Fixing Food, Bets Practices towards the Sustainable Development Goals; Economist Intelligence Unit: Parma, Italy, 2018.

92. FAO. The EX-Ante Carbon-Balance Tool for Value Chains (EX-ACT VC); Fact Sheet and App download; FAO: Rome, Italy, 2020. Available online: http:/ / www.fao.org/in-action/epic/ex-act-tool/suite-of-tools/ex-act-vc/en/ (accessed on 5 March 2021).

93. Alliance for Water Stewardship. The International Water Stewardship (AWS) Standard Version 2.0. 2019. Available online: https:/ /a4ws.org/wp-content/uploads/2019/03/AWS_Standard_2.0_2019_Final.pdf (accessed on 5 March 2021).

94. OECD. The Post-2020 Biodiversity Framework: Targets, Indicators and Measurability Implications at Global and National Level; Interim Report; OECD: Paris, France, 2019. Available online: https://www.oecd.org/environment/resources/biodiversity/report-thepost-2020-biodiversity-framework-targets-indicators-and-measurability-implications-at-global-and-national-level.pdf (accessed on 5 March 2021).

95. Janker, J.; Mann, S. Understanding the Social Dimension of Sustainability in Agriculture: A Critical Review of Sustainability Assessment Tools. Environ. Dev. Sustain. 2020, 22, 1671-1691. [CrossRef]

96. Instituto Ethos de Empresas e Responsabilidade Social; Indicadores Ethos de Responsabilidad Social Empresarial: Sao Paulo, Brazil, 2007.

97. Fair Trade International. Fairtrade Standard for Small-scale Producer Organizations Version 03.04.2019 v.2.4. Available online: https: / / files.fairtrade.net/SPO_EN.pdf (accessed on 2 July 2021).

98. IFPRI. Feed the Future Results Framework—Women's Empowerment in Agriculture Index; USAID: Washington, DC, USA, 2016. Available online: https:/ /cg-281711fb-71ea-422c-b02c-ef79f539e9d2.s3.us-gov-west-1.amazonaws.com/uploads/2019/05/20 16_ftf_gfss_chart_093016.pdf (accessed on 6 March 2021).

99. International Organization for Standardization. Contributing United Nations Sustainable Development Goals with ISO 26000; ISO: Geneva, Switzerland, October 2018; 18p.

100. ISEAL Alliances. Principles for Credible and Effective Sustainability Standards Systems ISEAL Credibility Principles; ISEAL: London, UK, June 2013; 18p. Available online: https:/ /www.isealalliance.org/defining-credible-practice/iseal-credibility-principles (accessed on 2 May 2021).

101. FiBL. SMART Sustainability Assessment Report, Farm: Peter Miller; Report Version 2016, SMART Farm Peter; University of Florence: Florence, Italy, 2016. Available online: https:/ / www.fibl.org/fileadmin/documents/de/themen/nachhaltigkeitsanalyse/smart/ 20170819_SMART_ExampleReport_EN_MedResolution.pdf (accessed on 6 March 2021).

102. UTZ. Core Code of Conduct for Individual and Multi-Site Certification; Version 1.1; The UTZ: Amsterdam, The Netherlands, 2015. Available online: https://utz.org/?attachment_id=3621 (accessed on 6 May 2021).

103. SCS Global Services/C.A.F.E. Practices—Guía de Referencia de Indicadores Para Verificadores e Inspectores—Starbucks Coffee Company-V3.4 Versión en Español-August 2019. Available online: https://cdn.scsglobalservices.com/files/program_ documents/CAFE_IndicatorGuidanceV3\%204_SPA_080119.pdf (accessed on 7 March 2021).

104. COSA. The COSA Measuring Sustainability Report: Coffee and Cocoa in 12 Countries; The Committee on Sustainability Assessment: Philadelphia, PA, USA, 2013.

105. Better Cotton Initiative (BCI). BCI Principles and Criteria. Version 2.1 March 2018. Available online: https:/ / bettercotton.org/wpcontent/uploads /2019/06/Better-Cotton-Principles-Criteria-V2.1.pdf (accessed on 6 March 2021).

106. Sen, A.K. The Ends and Means of Sustainability. J. Hum. Dev. Capab. Multi-Discip. J. People-Cent. Dev. 2013, 14, 6-20. [CrossRef]

107. Pick, B. Empirical Analysis of Geographical Indications in France and Vietnam: Opportunities and Constraints. Ph.D. Thesis, London School of Economics and Political Science, London, UK, 2018; 345p. 